\title{
Antena Spiral-dipole untuk Ground Penetrating Radar (GPR)
}

\section{Spiral Dipole Antenna for Ground Penetrating Radar (GPR)}

\author{
Yuyu Wahyu ${ }^{a}$, , Haryanto Sachrawi ${ }^{b}$, Asep Yudi Ha, dan Heroe Wijanto ${ }^{\mathrm{b}}$ \\ ${ }^{a}$ Pusat Penelitian Elektronika dan Telekomunikasi, Lembaga Ilmu Pengetahuan Indonesia \\ Komplek LIPI Gedung 20 Lantai 4, Jl Sangkuriang, Bandung 40135, Indonesia \\ ${ }^{b}$ Jurusan Teknik Telekomunikasi - IT Telkom \\ Bandung, Indonesia
}

\begin{abstract}
Abstrak
GPR (Ground Penetrating Radar) merupakan divais yang berguna untuk proses pendeteksian objek yang terkubur di bawah permukaan tanah hingga kedalaman tertentu, tanpa perlu dilakukan penggalian tanah. Pada penelitian ini dilakukan perancangan, simulasi dan realisasi antena spiral-dipole dengan pembebanan resistif untuk aplikasi impulse GPR. Pembebanan resistif bertujuan untuk menekan late-time ringing dan memperbesar bandwidth walaupun akan mengurangi efisiensi amplitudo pulsa utama. Late-time ringing merupakan osilasi yang mengikuti pulsa yang dikirimkan. Osilasi ini dapat mengaburkan sinyal yang dipantulkan oleh objek sehingga menyulitkan untuk dilakukan proses deteksi. Dengan melakukan perubahan nilai konstanta $k$ pada rumusan spiral Archimedes, maka didapatkan bentuk spiral dengan kerapatan yang berbeda-beda. Dalam tulisan ini, nilai konstanta $k$ yang digunakan antara lain 0,$5 ; 1$; dan 1,5 . Parameter yang dibahas dalam simulasi ini adalah amplitudo peak to peak pulsa utama maupun ringing yang dihasilkan dari masing-masing antena dengan nilai konstanta $k$ yang digunakan. Analisis elektromagnetik dalam domain waktu digunakan metode FDTD (finite-difference time-domain) dengan software FDTD3D untuk menghitung gelombang yang ditransmisikan antena dalam domain waktu. Selanjutnya dilakukan realisasi dan pengukuran antena tersebut.
\end{abstract}

Kata Kunci: antena GPR, impulse GPR, ultra wideband, antena spiral-dipole.

\section{Abstract}

GPR (Ground Penetrating Radar) is a device useful for the detection of objects buried under the ground to a certain depth, without the need for excavation. This research was carried out on the design, simulation and realization of spiral-dipole antennas with resistive load for impulse GPR applications. Imposition resistive aims to suppress late-time ringing and enlarge the bandwidth though will reduce the efficiency of the main pulse amplitude. A late-time ringing oscillations that follow the transmitted pulse. This oscillation can obscure the signal reflected by the object, making it hard to do the detection process. By changing the value of the constant $k$ in the formula Archimedes spiral, the spiral shapes obtained with different densities. In this the value of the constant $k$ used were $0.5,1,1.5$. The parameters discussed in this simulation is the peak to peak amplitude of the main pulse and ringing resulting from each antenna to the value of the constant $k$ is used. Electromagnetic analysis in the time domain FDTD method is used (finite-difference time-domain) with FDTD3D software to calculate the transmitted wave antenna in the time domain. Next step is the realization and measurement of the antenna.

Keywords: GPR antenna, GPR impulse, ultra wideband, spiral-dipole

I.

Pendahuluan

GPR (Ground Penetrating RADAR) merupakan alat yang berguna untuk pendeteksian objek yang berada di bawah permukaan medium (misalnya tanah atau beton, dll) dengan kedalaman tertentu tanpa perlu melakukan penggalian tanah. Dengan GPR maka informasi mengenai keadaan di bawah permukaan tanah dapat dilakukan dengan cepat dan mudah. Contoh penggunaan GPR antara lain mendeteksi kabel bawah tanah, fondasi bangunan, ranjau dan lain-lain.

\footnotetext{
* Corresponding Author

Email: yuyu@ppet.lipi.go.id

Received: November 11, 2013; Revised: : November 25, 2013

Accepted: Desember 23, 2013

Published: Desember 30, 2013

(c) 2013 PPET - LIPI

doi : 10.14203/jet.v13.39-46
}

Aplikasi GPR menggunakan pulsa sempit sebagai gelombang yang dipancarkan oleh antena pengirim yang akan mempunyai lebar bidang frekuensi yang luas. Hal inilah yang melatarbelakangi dibutuhkannya suatu antena yang dapat mempertahankan kestabilan pola radiasi untuk rentang frekuensi yang besar. Hal tersebut merupakan salah satu yang melatarbelakangi ide penggunaan antena ultra wideband pada aplikasi GPR [1].

Antena merupakan salah satu elemen terpenting dalam GPR. Kemampuan GPR dalam pendeteksian amat bergantung pada kemampuan antena yang digunakan. Hal ini disebabkan, antena adalah bagian yang meradiasikan pulsa sempit tersebut ke tanah dengan radiasi antena yang diharapkan memiliki tingkat loss dan distorsi yang kecil. Jika frekuensi rendah dalam GPR tidak diradiasikan secara maksimal maka akan terdapat refleksi internal yang mengakibatkan osilasi. 
Selanjutnya osilasi ini akan mengakibatkan gejala late time ringing yang akan mengaburkan sinyal pendeteksian yang mengakibatkan analisis benda menjadi sulit [2]. Pembebanan resistif dan penggunaan absorber digunakan untuk mengatasi refleksi internal tersebut. Antena ultra wideband yang biasa digunakan pada GPR adalah antena dipole setengah lamda. Antena dipole yang memiliki resistor yang dipasang tergulung di ujungnya disebut dengan antena rolled dipole atau spiral dipole.

Semakin tinggi frekuensi maka semakin tinggi juga pelemahan sinyal dalam perambatannya sehingga jarak jangkauan dari GPR akan semakin dangkal [3]. Tetapi di sisi lain resolusi frekuensinya yang selanjutnya akan mempengaruhi dari kualitas pencitraan akan semakin baik. Sehingga ada tradeoff antara kedalaman penetrasi dengan kualitas dari pencitraan. Dengan pertimbangan tersebut, antena yang digunakan didesain untuk eksitasi pulsa monocycle dengan durasi 1,6 ns (frekuensi pusat $600 \mathrm{MHz}$ ). Frekuensi tersebut cocok untuk aplikasi GPR resolusi menengah, yang digunakan untuk mendeteksi target yang kedalamannya kurang dari 1 meter (contohnya ranjau, pipa, dan kabel).

Untuk menganalisa kinerja antena, digunakan pemodelan numerik dengan metode Finite-Difference Time-Domain (FDTD) dengan menggunakan software FDTD3D. Pemilihan metode ini karena keunggulan yang dimilikinya, diantaranya: FDTD bekerja pada domain waktu di mana untuk rentang frekuensi yang lebar dapat diselesaikan hanya dengan sekali simulasi sehingga efektif jika digunakan pada sistem yang menggunakan pulsa monocycle sebagai sumber eksitasi. Kemudian FDTD memungkinkan pengguna untuk mendefinisikan sifat material pada semua titik di dalam domain simulasi, sehingga antena yang di desain lebih nyata atau realistis [4].

\section{DESAIN ANTENA}

\section{A. Pulsa yang Dibangkitkan}

Pulsa yang dibangkitkan pada antena GPR yang diusulkan ini adalah pulsa monocycle dengan durasi 1.6 ns seperti terlihat pada Gambar 1 (a). Gambar 1 (b) merupakan spektrum dari pulsa. Terlihat bahwa pulsa tersebut memiliki frekuensi tengah $600 \mathrm{MHz}$.

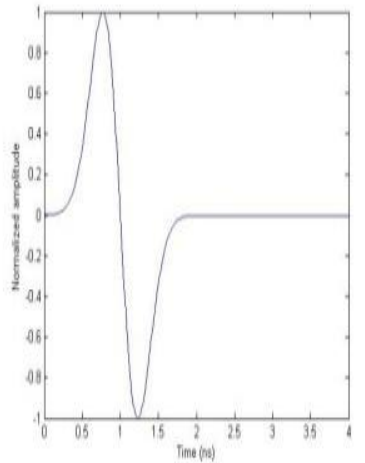

(a)

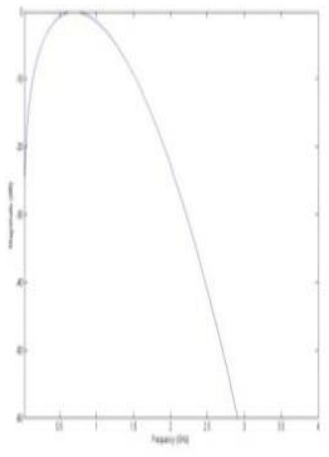

(b)
Gambar 1. Pulsa Yang Dibangkitkan oleh Antena : Pulsa 1,6 ns Monocycle Dengan Frekuensi Tengah $600 \mathrm{MHz}$, (a) Bentuk Gelombang, (b) Spektrum.

\section{B. Geometri Antena}

Dalam penelitian ini, antena GPR yang diusulkan yaitu antena spiral-dipole dengan pembebanan resistif. Penggunaan dipole tak lain adalah karena dipole merupakan antena yang sering digunakan untuk aplikasi GPR terutama dikarenakan kesederhana-annya. Permasalahan utama antena dipole untuk aplikasi ini adalah sifat dasarnya yang narowband, padahal untuk aplikasi GPR dibutuhkan antena dengan karakteristik ultra wideband. Untuk mengatasi hal ini, pada lengan antena dilakukan pembebanan resistif (lengan beban) dengan profil $\mathrm{Wu}$-King untuk mengurangi late-Time ringing akibat multiple reflection antara ujung antena dan feedpoint.

Penambahan lengan beban mengakibatkan dimensi antena yang semakin panjang. Untuk mengurangi dimensi panjang dari antena, maka lengan beban di gulung melingkar (spiral) ke bagian atas lengan yang tidak dilakukan pembebanan resistif hingga membentuk seperti spiral, seperti yang terlihat pada Gambar 2. Garis putus-putus menggambarkan lengan beban, sedangkan celah yang memisahkan garis merupakan tempat pembebanan resistif dengan menyisipkan elemen lumped resistor sesuai dengan profil Wu-King. Dengan menggulung antena, dimensi panjang antena dapat berkurang dengan faktor pengurangan sekitar 4 . Sehingga dari sisi ruang, jelas antena yang dirancang menjadi lebih efisien.

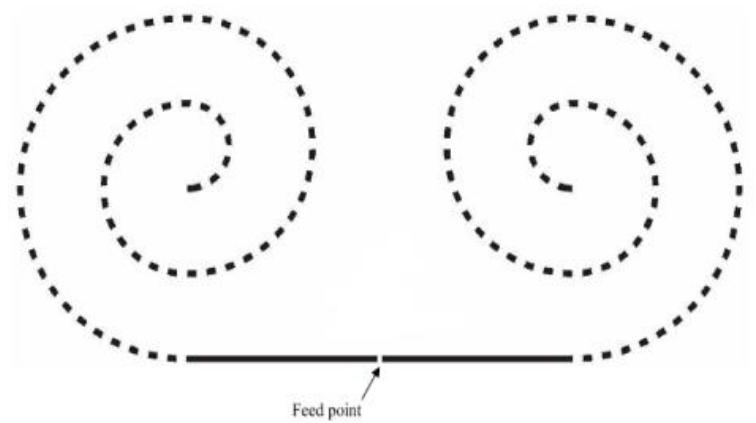

Gambar 2. Geometri Antena Spiral-Dipole. Celah yang memisahkan garis merupakan tempat diletakkannya resistor.

Pada resistor pertama (resistor yang paling dekat dengan feedpoint) terjadi diskontinuitas pada permukaan antena sehingga menyebabkan sumber radiasi kedua. Karena antena diharapkan mentransmisikan pulsa dengan efisiensi yang tinggi (dalam artian bahwa nilai pucak dari bentuk gelombang yang dikirim setinggi mungkin), maka harus ditentukan jarak antara feedpoint dengan resistor pertama sehingga radiasi dari resistor pertama saling menguatkan dengan radiasi dari feedpoint pada arah broadside antena. arah broadside antena dapat dicapai dengan membuat jarak antara feedpoint dengan resistor pertama $(l)$ sekitar $\lambda_{\mathrm{c}} / 4$, dimana $\lambda_{c}$ merupakan panjang gelombang dalam substrat pada frekuensi tengah pulsa. Secara matematis dapat dituliskan,

$$
2 l=\frac{c_{\text {subt }}}{2 f_{c}}
$$

di mana $f_{c}$ merupakan frekuensi tengah dari pulsa yang dibangkitkan yang memiliki nilai amplitudo tertinggi 


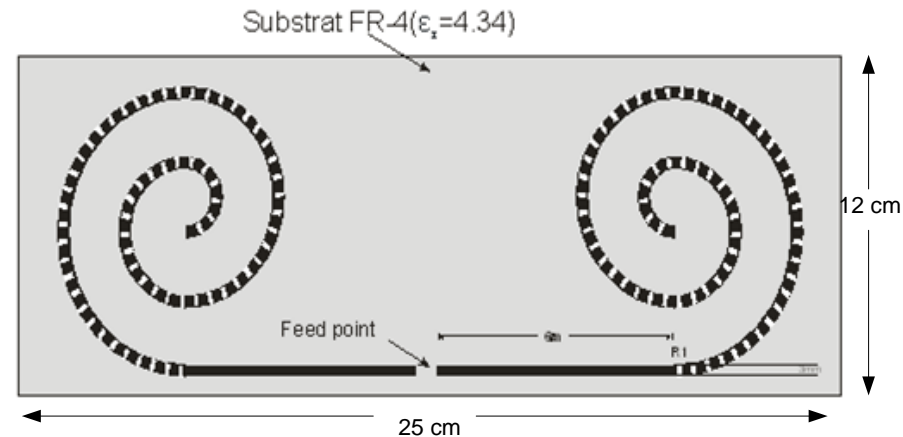

(a)

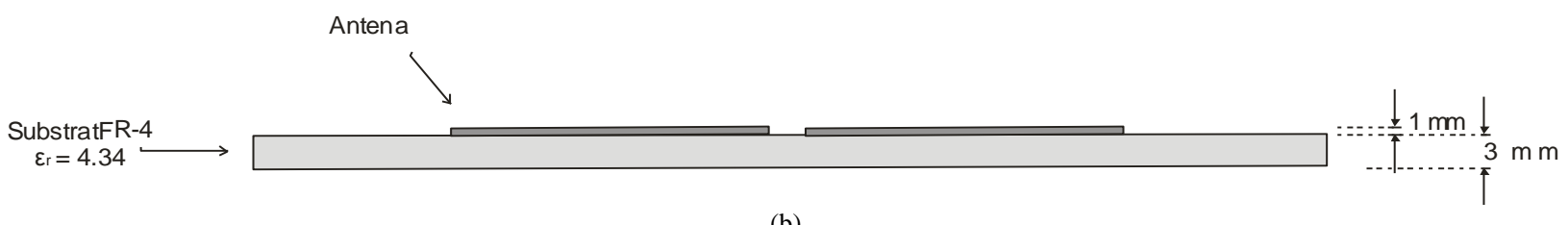

(b)

Gambar 3. Desain Geometri Antena Spiral-Dipole, (a) Tampak Depan, (b) Tampak Bawah.

dalam spektrum pulsa, dan $c_{\text {subt }}$ merupakan cepat rambat gelombang dalam substrat. Pada kasus printed antenna diatas substrat dielektrik, nilai $c_{\text {subt }}$ berbanding terbalik dengan permitivitas relatif dari bahan substrat. Jika permitivitas relatif substrat $\varepsilon_{\mathrm{r}}$ dan cepat rambat gelombang di udara bebas adalah $c$, maka $c_{\text {subt }}$ dapat dicari dengan persamaan,

$$
c_{\text {subt }}=\frac{c}{\sqrt{\varepsilon_{r}}}
$$

Dengan mensubtitusi Persamaan 1 dengan Persamaan 2, maka didapat jarak antara feedpoint dengan resistor pertama ( $l$ ) yaitu:

$$
l=\frac{c}{4 \sqrt{\varepsilon_{r}} f_{c}}
$$

Dengan memasukkan nilai $c=3 \times 10^{8} \mathrm{~m} / \mathrm{s}, f_{c}=600 \mathrm{MHz}$, dan $\varepsilon_{r}=4,34$ (dengan asumsi bahan substrat menggunakan FR-4). Maka didapat nilai $l$ sekitar $6 \mathrm{~cm}$. Gambar desain antena lebih detail dapat dilihat pada Gambar 3.

Selanjutnya dibuat 3 buah antena dengan kerapatan spiral yang berbeda-beda sesuai dengan 3 buah parameter $k$ yang ditentukan. Penggunaan 3 antena ditujukan untuk mendapatkan late-time ringing yang lebih baik. Ide dasar dari penelitian ini ialah kerapatan spiral yang berbeda akan menghasilkan late-time ringing yang berbeda.

\section{Pembebanan Antena}

Pembebanan resistif untuk menekan ringing diaplikasikan disepanjang lengan beban yang berbentuk seperti spiral. Pada penelitian ini, digunakan resistor sejumlah 25 buah yang dipasang secara seri dengan nilai resistansi yang semakin meningkat dengan profile resistor di perlihatkan pada gambar 4. Pemilihan jumlah ini dikarenakan keterbatasan dari numerical tool FDTD yang digunakan (software FDTD3D) untuk mendefinisikan materi di dalam domain komputasi. Jika jumlah resistor ditambah sehingga pendefinisian materi melebihi seribu baris, maka software ini akan error. Jumlah ini cukup memadai untuk menekan ringing sekaligus mempertahankan amplitudo pulsa utama. Pada prinsipnya, semakin banyak jumlah resistor, semakin efektif pula antena tersebut dapat menekan ringing. Tetapi hal ini dapat menurunkan efisiensi radiasi. Sehingga ada trade off antara level ringing yang ingin ditekan dengan efisiensi radiasi yang dihasilkan.

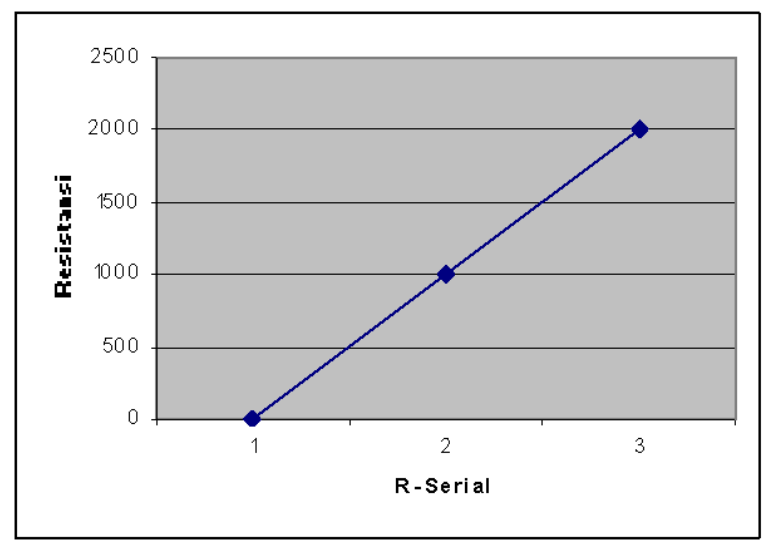

Gambar 4. Profil Resistor.

\section{SIMUlasi DAN ANALISIS FDTD3D}

Untuk mengamati parameter-parameter seperti VSWR, impedansi input, dan level ringing yang berubah-ubah berdasarkan kerapatan spiral antena, maka perlu dilakukan tahap simulasi. Simulasi dilakukan untuk membuktikan antena yang dirancang bekerja dengan baik setelah dilakukan tahap realisasi.

Simulasi yang dilakukan pada penelitian ini menggunakan metode FDTD sebagai alat untuk analisis secara teoritis. Pada aplikasinya software FDTD3D yang merupakan paket three dimensional finitedifference time-domain untuk menghitung medan elektromagnetik, yang ditulis dengan menggunakan bahasa $\mathrm{C}++$. 


\section{A. Simulasi dengan FDTD3D}

Simulasi software FDTD3D dengan pengaturan $\Delta \mathrm{x}$, $\Delta \mathrm{y}, \Delta \mathrm{z}=2,5 \mathrm{~mm}, \mathrm{nx}=61$ sel Yee ny $=61$ sel Yee $\mathrm{nz}=$ 301 sel Yee, diperlihat pada Gambar 5.

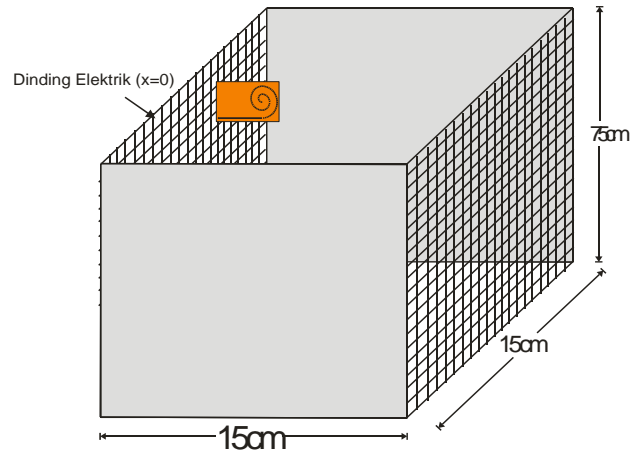

Gambar 5. Domain Komputasi Antena yang Disimulasikan Dengan FDTD.

Geometri Antena dari hasil simulasi yang diharapkan dan pendekatan geometri antena pada software FDTD3D diperlihatkan pada Gambar 6.

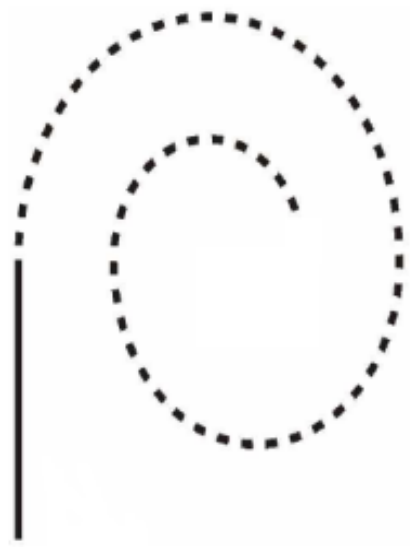

(a)

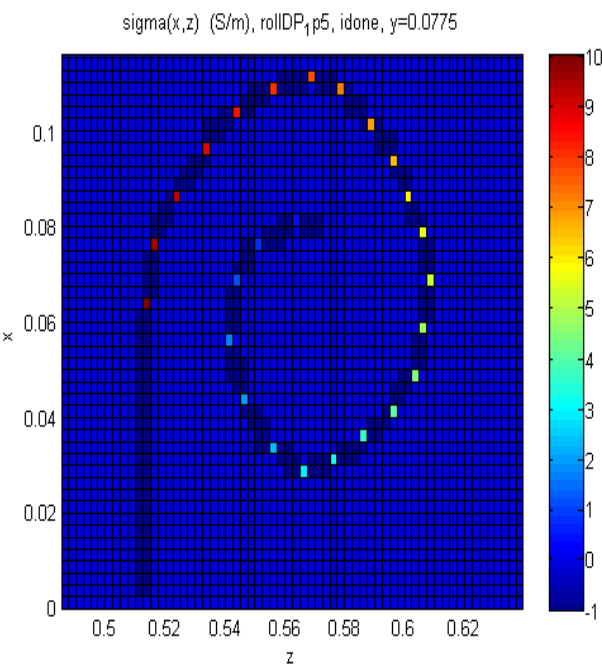

(b)

Gambar 6. (a) Geometri Antena yang Diharapkan, (b) Pendekatan Geometri Antena pada FDTD3D.

\section{B. Hasil Simulasi}

1) Geometri Antena Hasil Simulasi

Pada bagian ini diperlihatkan geometri antena yang digunakan.

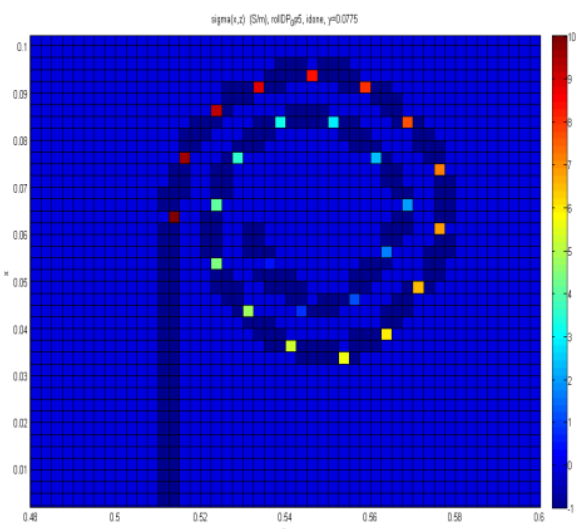

(a)

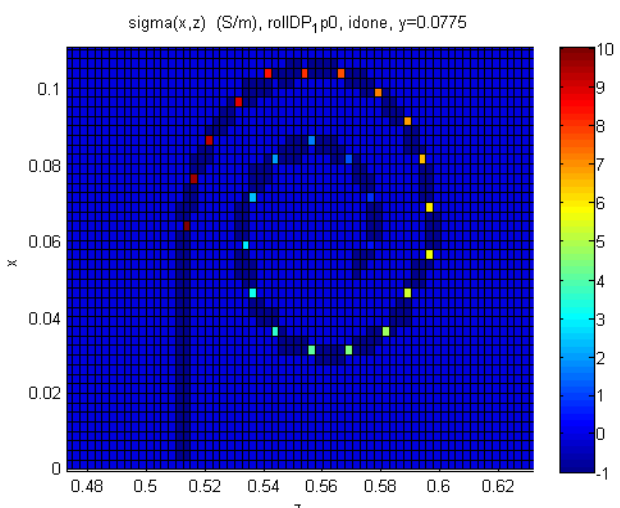

(b)

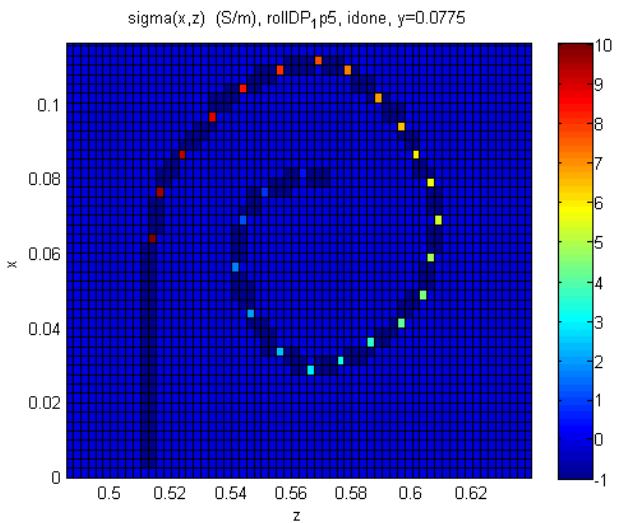

(c)

Gambar 7. Geometri Antena, (a) Dalam $k=0,5$,

(b) Dalam $k=1$, (c) Dalam $k=1,5$.

Geometri antena seperti yang terlihat di atas sudah mendekati perancangan. Walaupun terlihat patah-patah karena staircasing.

2) Hasil Simulasi Gelombang yang Ditransmisikan dan Ringing Antena Spiral-dipole pada Titik Pengamatan $25 \mathrm{~cm}$

Dilakukan simulasi gelombang yang ditransmisikan dan pada ringing antena spiral-dipole pada titik pengamatan dengan jarak $25 \mathrm{~cm}$, dan hasilnya ditunjukkan pada Gambar 8 dan Gambar 9. 


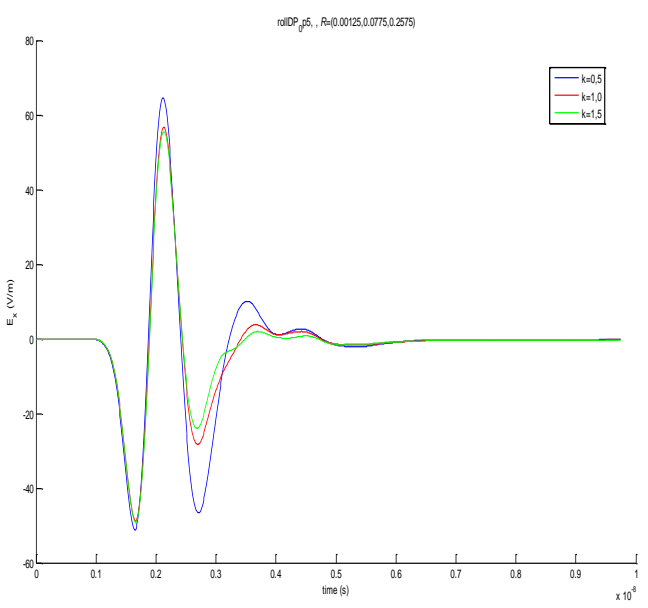

Gambar 8. Bentuk Gelombang yang Ditransmisikan oleh Antena Spiral-dipole Dengan Nilai $k=0,5 ; 1 ; 1,5$ pada Titik Pengamatan $25 \mathrm{~cm}$.

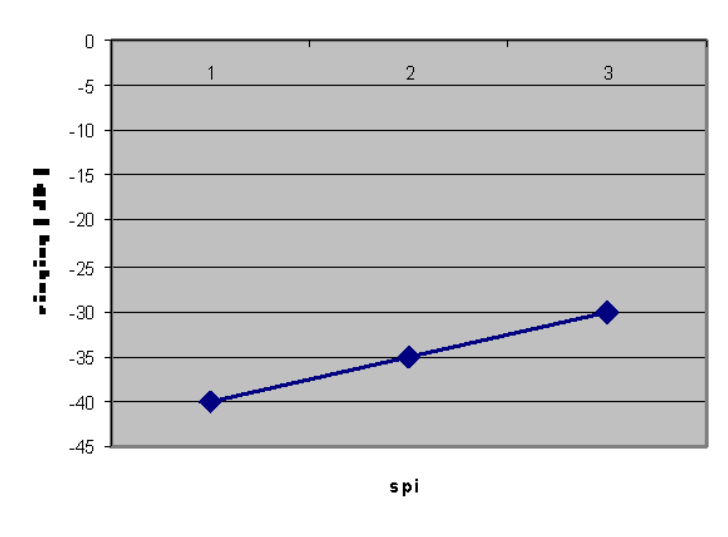

Gambar 9. Karakteristik Ringing Terhadap Nilai $k$ pada Titik Pengamatan $25 \mathrm{~cm}$ di Bawah Antena.

3) Hasil Simulasi Gelombang yang Ditransmisikan dan Ringing Antena Spiral-dipole pada Titik Pengamatan $50 \mathrm{~cm}$

Dilakukan simulasi gelombang yang ditransmisikan dan pada ringing antena spiral-dipole pada titik pengamatan dengan jarak $50 \mathrm{~cm}$, dan hasilnya ditunjukkan pada Gambar 10 dan Gambar 11.

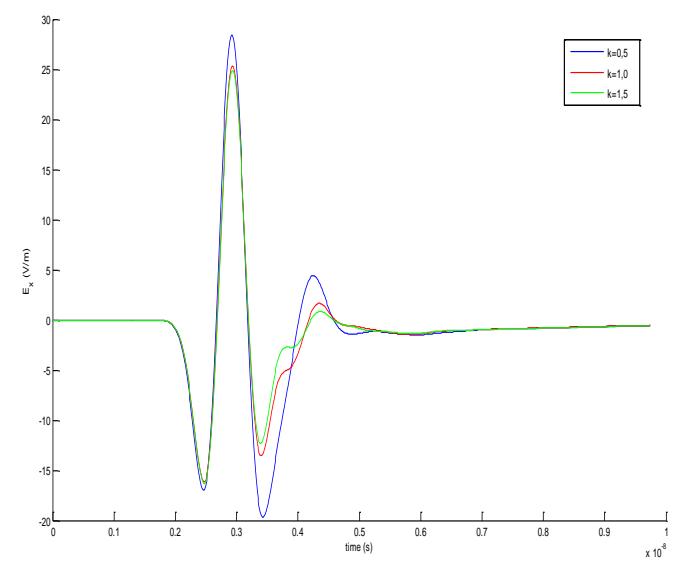

Gambar 10. Bentuk Gelombang yang Ditransmisikan oleh Antena Spiral-dipole Dengan Nilai $k=0,5 ; 1$; dan 1,5 pada Titik Pengamatan $50 \mathrm{~cm}$.

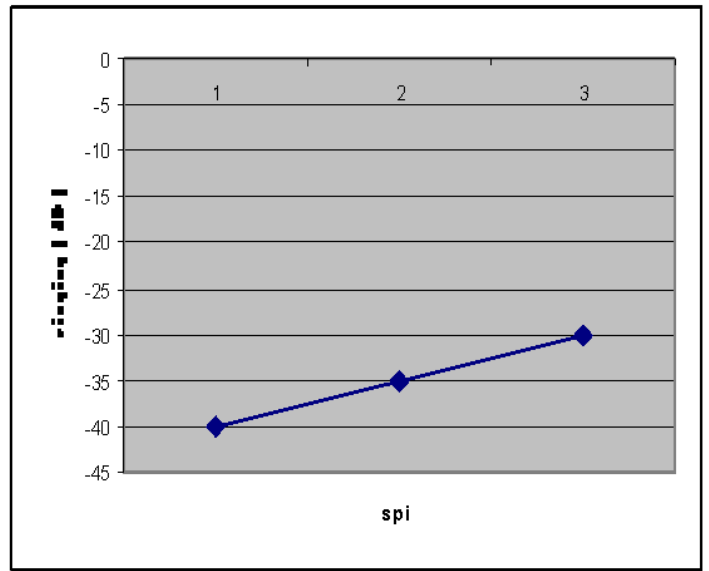

Gambar 11. Karakteristik Ringing Terhadap Nilai $k$ pada Titik Pengamatan $50 \mathrm{~cm}$ di Bawah Antena.

4) Hasil Simulasi Impedansi Input dan VSWR Antena Spiral-dipole.

Karekateristik hasil simulasi untuk impedansi dan VSWR antena spiral terhadap nilai $k$ diperlihatkan pada Gambar 12 dan Gambar 13.

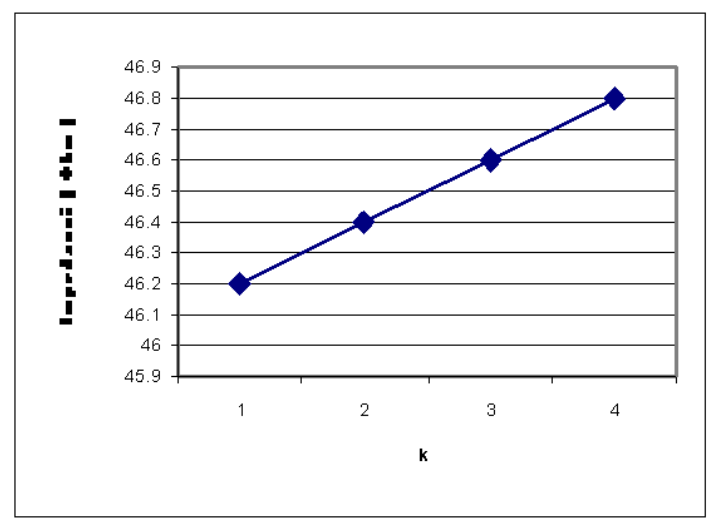

Gambar 12. Karakteristik Impedansi Antena Terhadap Nilai $k$.

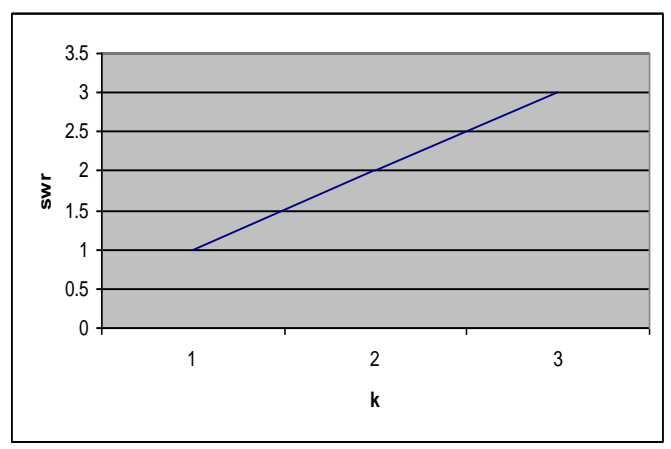

Gambar 13. Karakteristik VSWR Antena Terhadap Nilai $k$.

\section{Pengukuran Dan ANALisis}

\section{A. Realisasi Antena}

Untuk keperluan pengukuran guna mendapatkan data yang memadai terhadap kondisi sebenarnya di lapangan dari antena yang dirancang, telah dibuat realisasi dari antena yang telah dirancang sebelumnya dengan beberapa penyesuaian. Penyesuaian tersebut dilakukan terutama terhadap nilai-nilai komponen yang digunakan dalam perealisasian antena karena ketidaktersesediaan beberapa komponen tersebut di pasaran. Dalam perealisasian antena ini nilai-nilai 
komponen yang disesuaikan adalah nilai resistansi yang digunakan sebagai pembeban di sepanjang antena (resistive loading) dan nilai permitivitas relatif dari dielektrik yang digunakan sebagai bahan antena, sedangkan geometri antena sesuai dengan yang telah dideskripsikan pada bagian perancangan antena.

Untuk pembebanan resisitif digunakan thick film chip resistor yang dalam realisasinya disolder disepanjang lengan antena. Nilai-nilai resistansi di atas merupakan pendekatan dari nilai-nilai resistansi secara teoretis yang digunakan dalam perancangan antena.

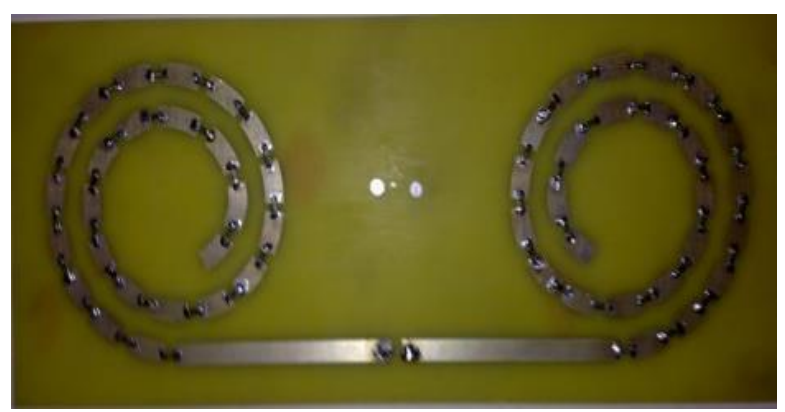

Gambar 14. Realisasi Antena untuk $k=0,5$.

Sedangkan sebagai bahan antena digunakan printer circuit board (PCB) FR-4 dengan tembaga sebagai lapisan logamnya dan permitivitas relatif dielektrik 4,1. Secara teoretis, penyesuaian nilai permitivitas dielektrik pada substrat yang digunakan dalam realisasi antena ini akan berpengaruh terhadap nilai peak-to-peak amplitudo maksimum pulsa yang ditransmisikan, akan tetapi tidak memberikan pengaruh yang signifkan terhadap bentuk gelombang yang ditransmisikan. Hal ini terjadi karena panjang antena yang optimum yang dioptimasi terhadap durasi pulsa berbanding terbalik dengan akar dari permitivitas bahan antena yang digunakan. Proses pabrikasi antena harus memiliki ketelitian dan keakuratan yang sangat tinggi, karena penyimpangan dalam orde antena cukup mempengaruhi karakteristik antenna secara umum.

Kemudian untuk feedpoint. Sebenarnya mekanisme perancangan yang baik untuk feedpoint dalam hal ini antena spiral-dipole adalah semakin pendek atau semakin dekat. Agar transmisi elektrik dari kabel semi rigid $($ TSR $=$ Twin Semi Rigid ) dapat maksimum menuju antena dengan sedikit yang hilang. Penggunaan jarak antar dua wire tersebut atau feedpoint dibuat $3 \mathrm{~mm}$ adalah karena faktor keamanan dan kemudahan. Penggunaan feedpoint yang semakin dekat, memungkinkan terjadinya konsleting pada TSR. Selain itu penggunaan feedpoint yang semakin dekat menyulitkan dalam hal penyolderan dengan TSR.

Dalam simulasi terlihat bahwa penggunaan feedpoint 3 mm cukup memberikan kontribusi yang cukup maksimum dalam pentransmisian elektrik.

Selain itu, pengunaan kabel semi rigid atau TSR (Twin Semi Rigid) ditujukan untuk menghindari penggunaan balun UWB yang harganya mahal dan sulit untuk diproduksi. Selain itu, TSR memiliki keunggulan dalam hal kemudahan setup ke antena yaitu tinggal disolder saja, harganya yang cukup murah dibandingkan dengan penyepadan antena seperti balun UWB, dan mudah dicari.

\section{B. Analisis Hasil Pengukuran}

Gelombang yang datang pada suatu antena akan terdapat dua perlakuan yang berbeda yaitu gelombang akan ditranasmisikan ke antena, dan gelombang tersebut akan dipantulkan kembali ke sumber. Gelombang pantul ini disebabkan karena ketidaksepadanan antara impedansi saluran dengan antenanya.

Pengukuran koefisien pantul ditujukan untuk mengetahui perbandingan antara gelombang pantul dengan gelombang datang. Superposisi antara gelobang pantul dengan gelobang datang akan membentuk suatu gelombang berdiri yang akan menghasilkan SWR yang merupakan perbandingan tegangan minimum dan tegangan maksimum pada gelombang berdiri.

Bandwidth antena merupakan range frekuensi kerja dimana performansi antena, yang bergantung pada beberapa karakteristik, berada pada standar tertentu. Bandwidth antena terletak antara frekuensi atas dan frekuensi bawah yang dibatasi oleh nilai VSWR tertentu. Batas VSWR semakin kecil, maka bandwith antena akan semakin lebar.

Pada pengukuran karakteristik ini menggunakan network analyzer dengan spesifikasi range frekuensi dari $(300 \mathrm{kHz}-20 \mathrm{GHz})$. Antena yang akan dibuat dalam penelitian ini, bisa menggunakan alat ini karena antena yang akan dibuat memiliki frekuensi kerja 600 $\mathrm{MHz}$.

\section{1) Pengukuran VSWR dan Impedansi Input}

Pengukuran VSWR dilakukan di LIPI dengan menggunakan network analyzer (NA) sebagai alat ukur dengan range frekuensi yang dapat diukur, yaitu (300 $\mathrm{KHz}$ - $20 \mathrm{GHz}$ ) dan Kabel TSR sebagai penghubung. Setup pengukuran impedansi input diilustrasikan pada Gambar 15, metoda pengukuran tersebut telah diperkenalkan oleh Lestari [5]. Salah satu ujung TSR line dihubungkan ke AUT sedangkan ujung lainnya dihubungkan dengan kabel koaksial 50 Ohm ke port 1 dan port 2 network analyzer (dikalibrasi pada konektor SMA) seperti yang terlihat pada Gambar 15.

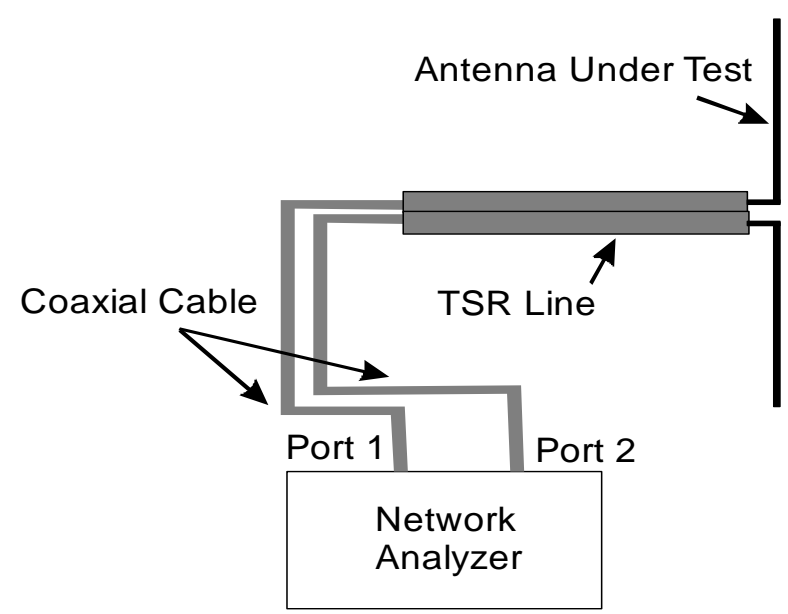

Gambar 15. Setup Pengukuran Impedansi Input Antena pada Domain Waktu.

Network analyzer memberikan hasil pengukuran $\mathrm{S}_{11}, \mathrm{~S}_{12}, \mathrm{~S}_{21}$, dan $\mathrm{S}_{22}$ dalam bentuk kompleks (real dan imajiner) sebanyak 401 data untuk masing-masing frekuensi dengan rentang antara $50 \mathrm{MHz}$ sampai dengan $5 \mathrm{GHz}$. Selanjutnya data ini diolah melalui software 


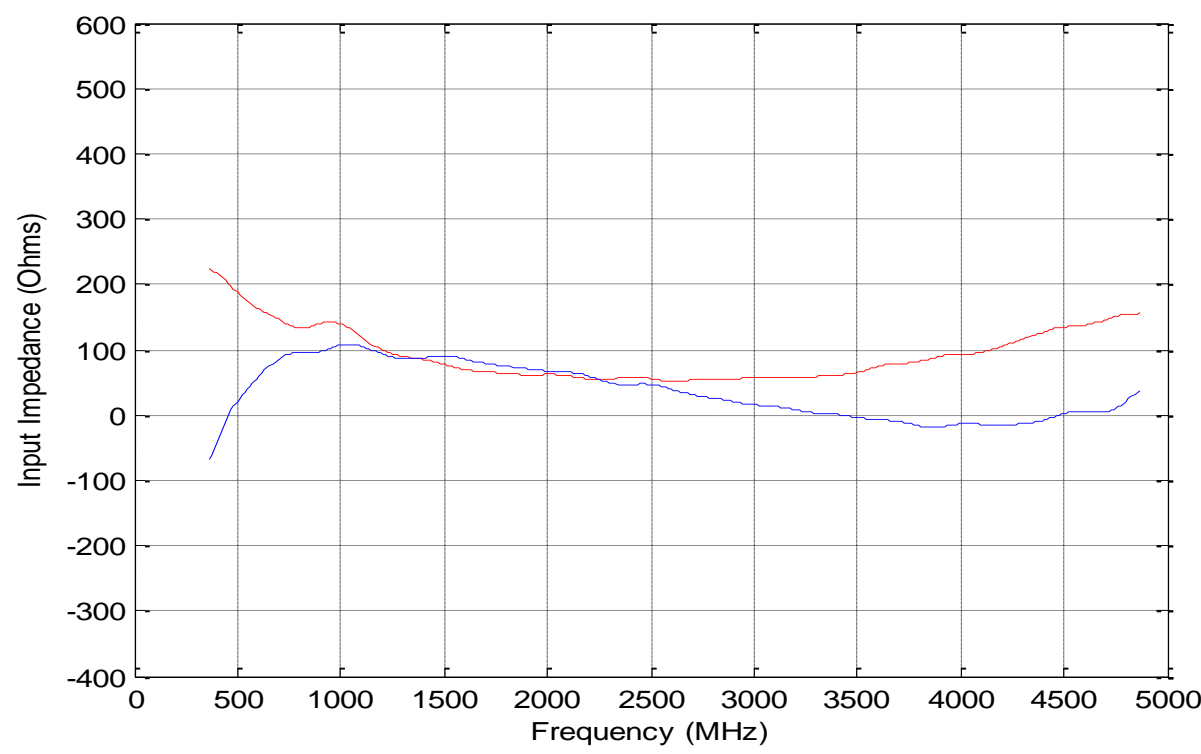

Gambar 16. Hasil pengukuran impedansi input untuk (a) $k=0,5$.

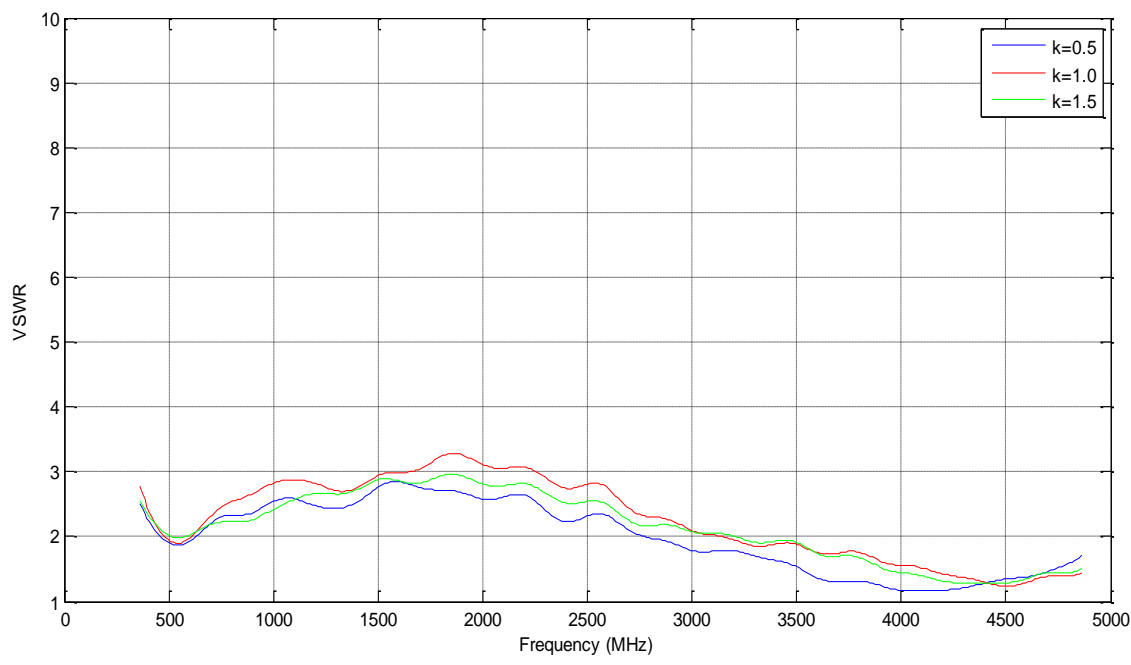

Gambar 17. Hasil pengukuran VSWR untuk $k=0,5 ; 1.0$; dan 1,5 .

post processing sehingga didapat harga impedansi input rata-rata dan VSWR antena. Hasil pengukuran di tunjukkan pada gambar 16 dan gambar 17.

\section{Ringkasan Pengukuran Antena Spiral-dipole}

1) Impedansi Input dan VSWR Antena Spiral-dipole

TABEL I

HASIL PENGUKURAN IMPEDANSI INPUT DAN VSWR ANTENA

\begin{tabular}{|c|c|c|c|c|c|}
\hline \multicolumn{2}{|c|}{} & \multicolumn{2}{c|}{ Simulasi FDTD } & \multicolumn{2}{c|}{ Pengukuran } \\
\cline { 3 - 6 } \multicolumn{2}{|c|}{} & Zin & VSWR & Zin & VSWR \\
\hline $\begin{array}{c}\text { Perubahan } \\
\text { Kerapatan } \\
\text { Spiral }\end{array}$ & $k=0,5$ & 46,471 & 1,14 & 172,63 & 1,94 \\
\cline { 2 - 6 } & $k=1,0$ & 46,481 & 1,47 & 180,46 & 1,99 \\
\cline { 2 - 6 } & $k=1,5$ & 46,631 & 1,59 & 188,47 & 2,03 \\
\hline
\end{tabular}

Tabel 1 menunjukkan rangkuman hasil pengukuran impedansi input, dan VSWR antena spiral-dipole baik hasil pengukuran maupun hasil simulasi FDTD. Hasil pengukuran impedansi input dalam perealisasian antena yang ditunjukkan pada Tabel 1 berkisar antara 172,63 ohm sampai $188.47 \mathrm{ohm}$ atau VSWR dari 1,94 sampai
2,03. Hasil pengukuran impedansi input ini berbeda dengan terminasi yang biasa dipakai dalam GPR dengan feed line TSR $100 \mathrm{ohm}$. Pengunaan kabel semi rigid atau TSR (Twin Semi Rigid) ditujukan untuk menghindari penggunaan balun UWB yang harganya mahal dan sulit untuk diproduksi. Selain itu, TSR memiliki keunggulan dalam hal kemudahan setup ke antena yaitu tinggal disolder saja, harganya yang cukup murah dibandingkan dengan penyepadan antena seperti balun UWB, dan mudah dicari. Sementara itu hasil pengukuran VSWR perealisasian antena menunjukkan nilai lebih besar dari hasil simulasi FDTD. Hal ini disebabkan perbedaan impedansi input antena dengan nilai impedansi output (TSR $100 \mathrm{ohm}$ ).

Oleh karena itu hasil dalam perealisasian antena di atas tidak baik untuk diambil sebagai acuan penelitian, tetapi hanya karakteristik antena yang layak diambil sebagai acuan penelitian. Karakteristik antena pada simulasi FDTD dan perealisasian memiliki kesamaan. Sehingga bisa disimpulkan untuk menentukan nilai VSWR antena yang baik atau yang mendekati hasil 
simulasi, maka harus digunakan Impedansi Output yang matching dengan Impedansi Input antena.

2) Perubahan Level Sinyal Utama dan Level Late Time Ringing Antena Spiral-dipole

TABEL II

Hasil Pengukuran LeVel Sinyal Utama DAN LATE TIME RINGING ANTENA

\begin{tabular}{|c|c|c|c|c|c|c|}
\hline \multirow{2}{*}{$\begin{array}{c}\text { Kerapatan } \\
\text { Spiral }\end{array}$} & \multicolumn{2}{|c|}{ Titik Pengamatan 25 cm } & \multicolumn{2}{|c|}{ Titik Pengamatan 50cm } \\
\cline { 2 - 7 } & $\begin{array}{c}\text { Vpp } \\
\text { Pulsa } \\
\text { Utama } \\
(\mathbf{V} / \mathbf{m})\end{array}$ & $\begin{array}{c}\text { Vpp } \\
\text { Ringing } \\
\text { (V/m) }\end{array}$ & $\begin{array}{c}\text { Level } \\
\text { Ringing } \\
(\mathbf{d B})\end{array}$ & $\begin{array}{c}\text { Vpp } \\
\text { Pulsa } \\
\text { Utama } \\
(\mathbf{V} / \mathbf{m})\end{array}$ & $\begin{array}{c}\text { Vpp } \\
\text { Ringing } \\
\text { (V/m) }\end{array}$ & $\begin{array}{c}\text { Level } \\
\text { Ringing } \\
(\mathbf{d B})\end{array}$ \\
\hline$k=0,5$ & 3433 & 176 & $-25,803$ & 2037,1 & 139,99 & $-23,258$ \\
\hline$k=1,0$ & 2981 & 147 & $-26,141$ & 1725 & 111 & $-23,829$ \\
\hline$k=1,5$ & 2658 & 122,99 & $-26,694$ & 1655 & 103 & $-24,119$ \\
\hline
\end{tabular}

Tabel 2 menunjukkan rangkuman hasil pengukuran Level sinyal utama dan Level Late Time Ringing antena spiral-dipole. Hasil pengukuran Late Time Ringing dalam perealisasian antena yang ditunjukkan pada Tabel 2 menunjukkan suatu karakterisitik yang sama dengan simulasi FDTD, yaitu semakin besar nilai $k$ (semakin renggang) maka semakin kecil ringing yang dihasilkan antena spiral-dipole. Jadi untuk merancang sebuah antena spiral-dipole yang baik, maka diperlukan perancangan yang benar yaitu semakin renggang kerapatan spiral pada antena akan menghasilkan ringing yang semakin kecil pula.

\section{KESIMPULAN}

Setelah melakukan semua proses perancangan, simulasi, realisasi, dan pengukuran antena GPR spiraldipole dengan kerapatan gulungan spiral sesuai parameter $k$ (Archimedean Spiral) yang dioptimasi terhadap pulsa 1,6 ns dapat disimpulkan bahwa,

a. Antena spiral-dipole dapat memperkecil dimensi dengan penggunaan elemen resistor yang dipasang tergulung, b. Panjang antena optimum yang dapat digunakan untuk menghasilkan radiasi maksimum bergantung pada substrat bahan dielektrik dan frekuensi center dari pulsa yang ditransmisikan,

c. Bentuk gulungan spiral yang dapat menghasilkan late time ringing yang kecil pada antena spiraldipole adalah antena dengan nilai $k$ yang lebih besar atau lebih renggang (dalam penelitian ini diperoleh pada antena dengan $k=1.5$ ),

d. Nilai VSWR dan Impedansi Input antena berbanding lurus dengan besar nilai $k$, semakin besar nilai $k$ maka nilai VSWR akan semakin besar (semakin buruk) dan nilai Impedansi Input antena juga semakin besar.

\section{UCAPAN TERIMA KASIH}

Kami mengucapkan terima kasih kepada PPET yang telah memfasilitasi peralatan ukur dan kepada staff subbid. Sarana Telekomunikasi yg telah banyak membantu.

\section{DAFTAR REFERENSI}

[1] B. Allen, M. Dohler, E. Okon, W. Malik, A. Brown, and D. Edwards, Ultra Wideband Antena and Propagation for Communication, Radar and Imaging, West Sussuex, England: John willey and Sons, 2007.

[2] H. M. Jol, Ground Penetrating Radar Theory and Aplications, Amsterdam, The Netherlands: Elseveir Science \& Technology, 2009.

[3] J. G. Maloney and G. S.Smith, "A study of transient radiation from the Wu-King resistif monopole-FDTD analisys and experimental measurement", IEEE Trans. Antennas Propagat., vol. 41, no .5, pp. 668-679, May 1993.

[4] D. J. Daniels, Ground-Penetrating Radar, The Institution of Electrical Engineers, London, United Kingdom, 2004

[5] A. A. Lestari, "Antennas for Improved Ground Penetratimg Radar: Modeling, Tools, Analisys and Design", Ph.D. Dissertation, Delft University of Technology, The Netherlands, 2003. 